\title{
Accumulation of heavy metals and human health risk assessment via the consumption of freshwater fish Mastacembelus armatus inhabiting, thermal power plant effluent loaded canal
}

\author{
Mehjbeen Javed ${ }^{*}$ and Nazura Usmani
}

\section{${ }^{*}$ Correspondence:}

mehjabeenjaved200@gmail. com

Aquatic Toxicology Research Laboratory, Department of Zoology, Aligarh Muslim University, Aligarh, Uttar Pradesh 202002, India

\begin{abstract}
Bioaccumulation of six heavy metals ( $\mathrm{Mn}, \mathrm{Fe}, \mathrm{Co}, \mathrm{Ni}, \mathrm{Cu}, \mathrm{Zn}$ ) in the muscle of highly consumed fish species (Mastacembelus armatus) were measured using atomic absorption spectrometer. Fe (213.29 mg/kg dry weight) concentration was the most, followed by Zn (186.19 mg/kg dry weight), Ni (58.98 mg/kg dry weight), Cu (41.36 mg/kg dry weight), Co (9.06 mg/kg dry weight) and $\mathrm{Mn}$ ( $9.03 \mathrm{mg} / \mathrm{kg}$ dry weight). Estimated daily intake of heavy metals was calculated by mean fish consumption rate $19.5 \times 10^{-3} \mathrm{~kg} /$ day, on the basis of a calculation of the amount of fish consumed by adult individuals (male and female). The studied fish species pose non carcinogenic risk for $\mathrm{Co}$ and $\mathrm{Ni}$ [target hazard quotient $(\mathrm{THQ})>1$ ] only. Hazard index (HI) was high. Carcinogenic risk (TR) posed by this fish for male and female was $3.43 \times 10^{-3}$ and $3.91 \times 10^{-3}$, respectively for $\mathrm{Ni}$ (the carcinogenic potency slope factor was available for $\mathrm{Ni}$ only). The study is an alert indicating that inhabitants who consume these fishes (particularly females) were at risk of $\mathrm{Co}$ and Ni toxicity. In India recommended guidelines have yet not been established for these heavy metals, which is essential for setting of toxicological standards.
\end{abstract}

Keywords: Heavy metals, Bioaccumulation, Dietary intake, Target hazard quotient, Carcinogenic risk, Human health risk

\section{Background}

Heavy metals are non-biodegradable and persistent and are known to cause deleterious effects on animal and human health (Davydova 2005; Javed and Usmani 2011, 2012). Both acute and prolonged exposures to heavy metals cause various diseases (Jarup 2003; Javed and Usmani 2013a, 2015). Dietary intake of toxic elements is the main route of exposure for most people (Calderon et al. 2003; Powers et al. 2003). Owing to industrialization, heavy metal pollution of aquatic ecosystems has become topic of concern worldwide. Fishes are on top of aquatic food chain and hence accumulate significant amount of heavy metals (Javed and Usmani 2013b, 2015) and become the source of heavy metal for consumers. Primarily fishes are consumed as they are one of the best sources of

(c) 2016 The Author(s). This article is distributed under the terms of the Creative Commons Attribution 4.0 International License (http://creativecommons.org/licenses/by/4.0/), which permits unrestricted use, distribution, and reproduction in any medium, provided you give appropriate credit to the original author(s) and the source, provide a link to the Creative Commons license, and indicate if changes were made. 
protein and polyunsaturated fatty acids (PUFA). According to American Heart Association (AHA) fishes are recommended twice a week to the adults with no history of heart attack (Kris-Etherton et al. 2002).

A comprehensive regional survey of heavy metals in food and an assessment of their risk to the general population is lacking. In the present study, the concentrations of $\mathrm{Mn}$, $\mathrm{Fe}, \mathrm{Co}, \mathrm{Ni}, \mathrm{Cu}$ and $\mathrm{Zn}$ in freshwater fish Mastacembelus armatus inhabiting the heavy metal laden Kasimpur canal were determined. The potential risks (non-carcinogenic and carcinogenic) of heavy metals by consuming contaminated fish for adult male and female individuals were also estimated.

\section{Methods}

Sample collection and preparation

Mastacembelus armatus (15 samples) were collected from Kasimpur canal $\left(28.013^{\circ} \mathrm{N}\right.$ and $78.126^{\circ}$ E), district Aligarh, India. Fishes were captured with the help of professional local fisherman during the month of May, 2015. The fishes were captured with the help of cast net. They were washed with distilled water and kept in ice box and then transferred to the laboratory for further treatment. All the experiments were approved by the institutional ethical committee of Department of Zoology, Aligarh Muslim University, Aligarh, India. M. armatus is highly consumed by large mass of population of Aligarh region. Fish muscle was excised and dried in an oven at $\pm 60{ }^{\circ} \mathrm{C}$ for $5-6 \mathrm{~h}$. It was then powdered in pestle and mortar.

\section{Estimation of heavy metals}

Heavy metals namely $\mathrm{Mn}, \mathrm{Fe}, \mathrm{Co}, \mathrm{Ni}, \mathrm{Cu}$ and $\mathrm{Zn}$ were assessed in the muscle of $M$. armatus. Dried tissue $(1 \mathrm{~g})$ was digested in analytical grade $\mathrm{HNO}_{3}: \mathrm{HClO}_{4}(4: 1)$. After digestion the samples volume were raised up to the mark $(50 \mathrm{ml})$, mixed thoroughly and used for the estimation of heavy metals using Atomic Absorption Spectrophotometer (Perkin Elmer, Analyst A 800) (Javed et al. 2015).

Instrument calibration standards were made by diluting the standard (1000 ppm) supplied by Wako Pure Chemical Industry Ltd., Japan. Analytical blanks were run in the same way as the samples and concentrations were determined using standard solutions prepared in the same acid matrix. The accuracy of the applied analytical procedure was tested using the certified reference material Dorm-2 (dogfish muscle, National Research Council, Canada) for investigated metals. Replicate analyses of these reference materials gave good accuracy, with recovery rates for metals between 97 and 104 \% for fish (Additional file 1: Table 1) provided as supplementary material.

\section{Calculation of health risk assessment for fish consumption}

The values of heavy metal accumulation in muscle were used to calculate the estimated daily intake of metals (EDI), target hazard quotients (THQ), hazard index (HI) and target cancer risk (TR) separately for adult male and female individuals.

\section{Estimated daily intake of metals (EDI)}

EDI is measured in (mg/kg body-weight/day) (Song et al. 2009). 
Table 1 Reference dose and carcinogenic potency slope factor, oral

\begin{tabular}{lll}
\hline Heavy metals & RfD $(\mathbf{m g} / \mathbf{k g} /$ day $)$ & CPSo $\left(\mathbf{m g} / \mathbf{k g}\right.$ bw-day $\left.\mathbf{~}^{\mathbf{1}}\right)$ \\
\hline $\mathrm{Mn}$ & $1.4 \times 10^{-1}$ & - \\
$\mathrm{Fe}$ & $7.0 \times 10^{-1}$ & - \\
$\mathrm{Co}$ & $3.0 \times 10^{-4}$ & - \\
$\mathrm{Ni}$ & $2.0 \times 10^{-2}$ & 1.7 \\
$\mathrm{Cu}$ & $4.0 \times 10^{-2}$ & - \\
$\mathrm{Zn}$ & $3.0 \times 10^{-1}$ & - \\
\hline
\end{tabular}

Data taken from USEPA 2011, 2012 respectively

$$
E D I=\frac{M c \times I R}{B w \times 10^{-3}}
$$

where, Mc is the metal concentration in the fish muscle ( $\mathrm{mg} / \mathrm{kg}$ dry weight). IR is the ingestion rate, which is taken as $19.5 \times 10^{-3} \mathrm{~kg} /$ day as taken by previous studies (Little et al. 2002; Speedy 2003) and this consumption rate was used in health-risk assessment. The assumption of an adult ingestion rate of fish over a lifetime is a high estimate of actual fish consumption. BW is an average body weight of Indian male which is taken as $57 \mathrm{~kg}$ and that of female as $50 \mathrm{~kg}$ (Shukla et al. 2002).

\section{Target Hazard Quotient (THQ)}

To assess the human health risk from consuming the fish contaminated with heavy metals, the target hazard quotient (THQ) was calculated as per US EPA Region III RiskBased Concentration Table [USEPA (United States Environmental Protection Agency) 2011]. The THQ is an estimate of the non-carcinogenic risk level due to pollutant exposure and calculated by the following equation:

$$
T H Q=\frac{\left(M_{c} \times \mathrm{IR} \times 10^{-3} \times \mathrm{EF} \times \mathrm{ED}\right)}{(R f D \times B W \times A T n)}
$$

where, THQ is non-carcinogenic risk and is dimensionless. EF is the exposure frequency (365 days/year). ED is the exposure duration (67 years) (life expectancy of male $=65$ years approx. and for females is 68 years approx. in India, therefore an average of two extremes have been taken). RfD is the reference dose of individual metal (mg/kg/ day) [USEPA (United States Environmental Protection Agency) 2012] (Table 1). ATn is the averaging time for non-carcinogens (365 days/year $\times$ ED) [USEPA (United States Environmental Protection Agency) 2011].

\section{Hazard Index (HI)}

To assess the overall potential health risk posed by more than one metal, THQ of every metal is summed up and is known as hazard index (HI). The HI can be calculated by the sum of the target hazard quotients of each metal [USEPA (United States Environmental Protection Agency) 2011].

$$
\mathrm{HI}=\mathrm{THQMn}+\mathrm{THQFe}+\mathrm{THQCo}+\mathrm{THQNi}+\mathrm{THQCu}+\mathrm{THQZn}
$$




\section{Target Cancer Risk (TR)}

Target cancer risk (TR) is used to indicate the carcinogenic risk. The method which is used to estimate TR is provided in USEPA Region III Risk-Based Concentration Table [USEPA (United States Environmental Protection Agency) 2011]. It is dimensionless. TR was calculated by the following equation:

$$
T R=\frac{M_{c} \times \mathrm{IR} \times 10^{-3} \times \mathrm{CPSo} \times \mathrm{EF} \times \mathrm{ED}}{\mathrm{BW} \times \mathrm{ATc}}
$$

where $\mathrm{M}_{\mathrm{C}}$, IR, EF, ED, BW are already explained above. CPSo is the carcinogenic potency

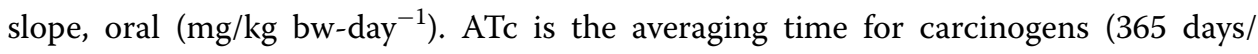
year $\times 67$ years), since in India the average life expectancy for males is 65 years (approx.) and for females is 68 years (approx.), therefore an average of two extremes have been taken for carcinogenic averaging time (http://countryeconomy.com/demography/ life-expectancy/india).

Since $\mathrm{Mn}, \mathrm{Fe}, \mathrm{Co}, \mathrm{Cu}$ and $\mathrm{Zn}$ do not cause any carcinogenic effects as their CPSo have yet not been established (USEPA 2012) so, TR value for intake of only Ni was calculated to show the carcinogenic risk. Its slope factor oral (CPSo) is the calculated slope as fixed by USEPA (2012) is given in Table 1.

There are certain assumptions which should be taken while evaluating the THQ for human health risk which are as follows:

(a) Ingested dose of pollutant is equal to the absorbed dose [USEPA (United States Environmental Protection Agency) 1989].

(b) Cooking has no effect on pollutants (Forti et al. 2011).

\section{Results and discussion}

\section{Bioaccumulation of heavy metals in muscle of fish}

The concentration of different heavy metals $(\mathrm{Mn}, \mathrm{Fe}, \mathrm{Co}, \mathrm{Ni}, \mathrm{Cu}, \mathrm{Zn})$ in the edible part (muscle) of fishes collected from Kasimpur canal is given in Table 2. Fe $(213.29 \mathrm{mg} / \mathrm{kg}$ dry weight) accumulated the most, followed by $\mathrm{Zn}(186.19 \mathrm{mg} / \mathrm{kg}$ d.w.), Ni $(58.98 \mathrm{mg} / \mathrm{kg}$ d.w.), $\mathrm{Cu}$ (41.36 mg/kg d.w.), Co (9.06 mg/kg d.w.) and Mn (9.03 mg/kg d.w.). Accumulations of heavy metals in tissues of other fishes have also been reported from the region (Javed et al. 2016a, b).

In the current study muscle was particularly selected for heavy metal analysis because it is the only edible tissue and thus concentration of toxicants in it was of concern.

Table 2 Heavy metal concentration ( $\mathrm{mg} / \mathrm{kg}$. d.w) in muscle of $M$. armatus

\begin{tabular}{lrl}
\hline Heavy metals & \multicolumn{1}{c}{ Muscle } & Recommended limits (ppm) \\
\hline $\mathrm{Mn}$ & $9.03 \pm 0.04$ & 1.0 (FAO/WHO 1989) \\
$\mathrm{Fe}$ & $213.29 \pm 0.48$ & 100 (FAO/WHO 1989) \\
$\mathrm{Co}$ & $9.06 \pm 0.04$ & $* *$ \\
$\mathrm{Ni}$ & $58.98 \pm 0.06$ & $70-80$ (USFDA 1993) \\
$\mathrm{Cu}$ & $41.36 \pm 0.38$ & 30 (FAO/WHO 1983) \\
$\mathrm{Zn}$ & $186.19 \pm 0.12$ & 100 (FAO/WHO 1989) \\
\hline
\end{tabular}

All values are given as mean $\pm \operatorname{SEM}(n=15) ;{ }^{* *}$ No guidelines 
Accumulation of $\mathrm{Mn}, \mathrm{Fe}, \mathrm{Cu}$ and $\mathrm{Zn}$ was higher than the recommended guidelines (FAO/WHO 1983, 1989; USFDA 1993). Therefore, human health risk assessment was carried out to estimate the risk posed by these metals.

\section{Human health risk assessment}

Estimated daily intake (EDI), Target hazard quotient (THQ), Hazard index (HI) and Target cancer risk (TR) values of metals via consumption of fish $M$. armatus are given in Table 3.

EDI values were many folds higher than the respective reference doses.

THQ was highest for $\mathrm{Co}$ followed by $\mathrm{Ni}>\mathrm{Cu}>\mathrm{Zn}>\mathrm{Fe}>\mathrm{Mn}$ for both male and female individuals.

High HI value was estimated for both females (13.71) and males (12.02).

Females $\left(3.91 \times 10^{-3}\right)$ were more prone to carcinogenic risk (TR) than males $\left(3.43 \times 10^{-3}\right)($ for $\mathrm{Ni})$.

According to Environmental Protection Agency (EPA) human health risk assessment is defined as the process to estimate the nature and probability of adverse health effects in humans exposed to chemicals in contaminated environmental media, now or in the future (http://www.epa.gov/risk_assessment/health-risk.htm). Risk assessment for heavy metals is estimated using parameters viz estimated daily intake (EDI), target hazard quotient (THQ), hazard index (HI) and target cancer risk (TR). These parameters for risk assessment were introduced by EPA in the United States for the estimation of potential health risk caused by any chemical contaminant over prolonged exposure [USEPA (United States Environmental Protection Agency) 1989]. These parameters depend not only on intake amount of contaminant but also deal with exposure frequency and duration, average body weight and oral reference dose (RfD). THQ is a dimensionless quantity and is a ratio of concentration of heavy metal content in the food item to its RfD, weighed by duration and frequency of exposure, intake amount and body weight (Harmanescu et al. 2011). THQ should not exceed 1, else it indicates to pose potential non carcinogenic risks to exposed population (Abdou and Hassan 2014; Harmanescu et al. 2011; Jovic and Stankovic 2014). It should also be noted that THQ is not a measure of risk but it reflects the level of concern (Harmanescu et al. 2011; Khan et al. 2009).

In the present study Co and Ni both show THQ values $>1$. Moreover, the THQ values for all concerned heavy metals were comparatively higher in females than males. This could be due to the differences in average weight and lifespan hence the risk assessment

Table 3 Estimated daily intake (EDI), Target hazard quotient (THQ), Hazard index (HI) and Target cancer risk (TR) values of metals via consumption of fish M. armatus

\begin{tabular}{|c|c|c|c|c|c|c|c|c|}
\hline \multirow{2}{*}{$\begin{array}{l}\text { Heavy } \\
\text { metals }\end{array}$} & \multicolumn{2}{|c|}{ EDI (mg/kg body-weight/day) } & \multicolumn{2}{|l|}{ THQ } & \multicolumn{2}{|l|}{$\mathrm{HI}$} & \multicolumn{2}{|l|}{ TR } \\
\hline & Male & Female & Male & Female & Male & Female & Male & Female \\
\hline $\mathrm{Mn}$ & $3.08 \times 10^{-3}$ & $3.5 \times 10^{-3}$ & 0.022 & 0.025 & 12.02 & 13.71 & - & - \\
\hline $\mathrm{Fe}$ & $7.29 \times 10^{-2}$ & $8.31 \times 10^{-2}$ & 0.104 & 0.118 & & & - & - \\
\hline Co & $3.09 \times 10^{-3}$ & $3.53 \times 10^{-3}$ & 10.33 & 11.77 & & & - & - \\
\hline $\mathrm{Ni}$ & $2.02 \times 10^{-2}$ & $2.30 \times 10^{-2}$ & 1.008 & 1.15 & & & $3.43 \times 10^{-3}$ & $3.91 \times 10^{-3}$ \\
\hline $\mathrm{Cu}$ & $1.41 \times 10^{-2}$ & $1.61 \times 10^{-2}$ & 0.353 & 0.403 & & & - & - \\
\hline $\mathrm{Zn}$ & $6.37 \times 10^{-2}$ & $7.26 \times 10^{-2}$ & 0.212 & 0.242 & & & - & - \\
\hline
\end{tabular}


parameters namely EDI, THQ and TR were calculated separately for adult male and female individuals. According to New York State Department of Health [NYSDOH (New York State Department of Health) 2007], if the ratio of EDI of heavy metal to its RfD was equal to or less than the RfD then the risk will be minimum. But if it is $>1-5$ times the RfD then risk will be low, if $>5-10$ times the RfD then risk will be moderate, however, if $>10$ times the RfD then the risk will be high. Ratio obtained for Mn, was approximately two folds higher for $\mathrm{Ni}$. $\mathrm{Cu}$ and $\mathrm{Zn}$ around seven folds and for Co several thousand times higher than their RfD, indicating potential health hazard to the public. Among the concerned heavy metals it is Co whose permissible limit has yet not been established by any agency in the world and as well as India.

THQ deal with individual heavy metal only, but generally food items contain more than one heavy metal as already seen in the case of fish muscle, six heavy metals were detected. So it becomes mandatory to calculate hazard index (HI). It is the numerical sum of all the THQs calculated for the fish fillet. Like THQ it should also not exceed 1 (Islam et al. 2014; Zodape 2014), if does then it is an alarm for public health concern. Adult females were found to be more prone to heavy metal risk than males (Vahter et al. 2002).

Among these concerned heavy metals $\mathrm{Cr}$ and $\mathrm{Ni}$ are mentioned in the list of potent carcinogens [USEPA (United States Environmental Protection Agency) 2012]. Cr was not detected hence target carcinogenic risk (TR) was calculated for Ni only. According to New York State Department of Health [NYSDOH (New York State Department of Health) 2007] the TR categories are described as, if TR $\leq 10^{-6}=$ Low; $10^{-4}$ to $10^{-3}=$ moderate; $10^{-3}$ to $10^{-1}=$ high; $\geq 10^{-1}=$ very high. In the study Ni shows high cancer risk to the exposed population. Like THQ the estimated lifetime cancer risk (TR) is also not a specific estimate of expected cancers. Rather, it is apparently an upper limit of the probability that the individuals may have cancer sometime his/her lifetime following exposure to that toxicant [NYSDOH (New York State Department of Health) 2007].

There are limits of intake even for the essential metals. Studies have shown that high intake of $\mathrm{Fe}$ and $\mathrm{Mn}$ is responsible for the deposition of iron oxides as has been reported in case of Parkinson's disease [FDA (Food and Drug Agency) 2001; Powers et al. 2003]. $\mathrm{Mn}$ is essential element for both animals and plants and its deficiency results in severe skeletal and reproductive abnormalities in mammals (Sivaperumal et al. 2007). Co is essential for human health as it forms part of Vitamin $B_{12}$ and around 0.16-1.0 mg/kg body weight is given to treat anemia [Agency for Toxic Substances and Disease Registry (ATSDR) 2004]. Short term exposure of rats to high doses of Co in food resulted in adverse health effects on blood, liver, kidney and heart [Agency for Toxic Substances and Disease Registry (ATSDR) 2004]. Based on the animal data of acute and chronic exposure to Co, the International Agency for Research on Cancer (IARC) has determined that it is possibly carcinogenic to humans [Agency for Toxic Substances and Disease Registry (ATSDR) 2004]. Excess of $\mathrm{Cu}$ is also found to be associated with liver damage. Excess of $\mathrm{Zn}$ show adverse nutrient interactions with $\mathrm{Cu}$ which means that high $\mathrm{Zn}$ concentration or intake around (50 mg/day) over a period of weeks can interfere with the availability of $\mathrm{Cu}$ to the body (King and Cousins 2006; Powers et al. 2003). According to King and Cousins (2006) high intake of $\mathrm{Zn}$ induces production of $\mathrm{Cu}$ binding proteins (metallothionein) in intestine which traps $\mathrm{Cu}$ within intestinal cells and prevents its systemic absorption. In addition to this excess $\mathrm{Zn}$ reduces immune function and the levels 
of high density lipoprotein (HDL) [FDA (Food and Drug Agency) 2001]. Ni normally occurs at very low levels in the environment and it may cause deleterious effects on pulmonary, like lung inflammation, fibrosis, emphysema and tumors (Forti et al. 2011).

\section{Conclusion}

It may therefore be concluded that M. armatus in the study undertaken is not acceptable for either human consumption or their use in animal feeds. Its use is limited by Co and Ni. In addition to protein, fishes also serve as rich source of poly unsaturated fatty acids (PUFA) and so they are highly recommended in diet. It is a popular food fish both in urban and rural areas and India is one of the largest contributors of fish fillet in International markets. Therefore fishes if dwelling in contaminated waters should be consumed with caution lest it may cause carcinogenic and non-carcinogenic risks to the exposed population. This study contributes significant data to the various agencies of India in particular and other agencies like United States Environmental Protection Agency (USEPA), Federal Environmental Protection Agency (FEPA) etc. in general which work for the development of toxicological standards.

\section{Additional file}

Additional file 1: Table 1. Concentrations of metals found in Standard Reference Material DORM-2 (dogfish muscle) from the National Research Council, Canada (all data as mean \pm standard deviation, in $\mathrm{mg} \mathrm{kg}^{-1}$ dry weight).

Authors' contributions

MJ carried out the whole experimental work. NU guiding the protocol and assist in calculation and drafting the manuscript. Both authors read and approved the final manuscript.

\section{Acknowledgements}

The authors wish to thank the Chairman Department of Zoology for providing the necessary facilities.

\section{Competing interests}

The authors declare that they have no competing interests.

Received: 5 December 2015 Accepted: 30 May 2016

Published online: 18 June 2016

\section{References}

Abdou HM, Hassan MA (2014) Protective role of omega-3 polyunsaturated fatty acid against lead acetate-induced toxicity in liver and kidney of female rats. BioMed Res Int. doi:10.1155/2014/435857

Agency for Toxic Substances and Disease Registry (ATSDR) (2004) Division of Toxicology, Clifton Road, Atlanta. http:// www.atsdr.cdc.gov/toxprofiles

Calderon J, Ortiz-Perez D, Yanez L, Diaz-Barriga F (2003) Human exposure to metals. Pathways of exposure, biomarkers of effect, and host factors. Ecotoxicol Environ Saf 56:93-103

Davydova S (2005) Heavy metals as toxicants in big cities. Microchem J 79:133-136

FAO, WHO (1983) Compilation of legal limits for hazardous substances in fish and fishery products. Fish Circular 464:5-100

FAO/WHO (1989) National Research Council Recommended Dietary Allowances (10th ed). National Academy Press, Washington, DC

FDA (Food and Drug Agency) (2001) Fish and fisheries products hazards and controls guidance, 3rd edn. Center for Food Safety and Applied Nutrition, US Food and Drug Administration, Silver Spring

Forti E, Salovara S, Cetin Y, Bulgheroni A, Pfaller RW, Prieto P (2011) In vitro evaluation of the toxicity induced by nickel soluble and particulate forms in human airway epithelial cells. Toxicol In Vitro 25:454-461

Harmanescu M, Alda LM, Bordean DM, Gogoasa I, Gergen I (2011) Heavy metals health risk assessment for population via consumption of vegetables grown in old mining area; a case study: Banat County, Romania. Chem Central J 5:64

Islam MS, Ahmed MK, Al-Mamun MH, Islam KN, Ibrahim M, Masunaga S (2014) Arsenic and lead in foods: a potential threat to human health in Bangladesh. Food Add Contam Part A. doi:10.1080/19440049.2014.974686

Jarup L (2003) Hazards of heavy metal contamination. Br Med Bull 68:167-182 
Javed M, Usmani N (2011) Accumulation of heavy metals in fishes: a human health concern. Int J Environ Sci 2:659-670 Javed M, Usmani N (2012) Toxic effects of heavy metals ( $\mathrm{Cu}, \mathrm{Ni}, \mathrm{Fe} \mathrm{Co}, \mathrm{Mn}, \mathrm{Cr}, \mathrm{Zn})$ to the haematology of Mastacembelus armatus thriving in Harduaganj Reservoir, Aligarh, India. Global J Med Res 12:59-64

Javed M, Usmani N (2013a) Investigation on accumulation of toxicants and health status of freshwater fish Channa punctatus, exposed to sugar mill effluent. Int J Zoo Res 3:43-48

Javed M, Usmani N (2013b) Assessment of heavy metal (Cu, Ni, Fe Co, Mn, $\mathrm{Cr}, \mathrm{Zn}$ ) pollution in effluent dominated rivulet water and their effect on glycogen metabolism and histology of Mastacembelus armatus. Springer Plus 2:1-13

Javed M, Usmani N (2015) Stress response of biomolecules (carbohydrate, protein and lipid profiles) in fish Channa punctatus inhabiting river polluted by thermal power plant effluent. Saudi J Bio Sci. doi:10.1016/j.sjbs.2014.09.021

Javed M, Usmani N, Ahmad I, Ahmad M (2015) Studies on the oxidative stress and gill histopathology in Channa punctatus of the canal receiving heavy metal-loaded effluent of Kasimpur Thermal Power Plant. Environ Monit Assess 187:4179. doi:10.1007/s10661-014-4179-6

Javed M, Ahmad I, Usmani N, Ahmad M (2016a) Bioaccumulation, oxidative stress and genotoxicity in fish (Channa punctatus) exposed to a thermal power plant effluent. Ecotoxicol Environ Saf 127:163-169

Javed M, Ahmad I, Usmani N, Ahmad M (2016b) Studies on biomarkers of oxidative stress and associated genotoxicity and histopathology in Channa punctatus from heavy metal polluted canal. Chemos 151:210-219

Jovic M, Stankovic S (2014) Human exposure to trace metals and possible public health risks via consumption of mussels Mytilus galloprovincialis from the Adriatic coastal area. Food Chem Toxicol 70:241-251

Khan S, Farooq R, Shahbaz S, Khan MA, Sadique M (2009) Health risk assessment of heavy metals for population via consumption of vegetables. World App Sci J. 6:1602-1606

King JC, Cousins RJ (2006) Zinc. In: Shils ME, Shike M, Ross AC, Caballero B, Cousins RJ (eds) Modern nutrition in health and disease, 10th edn. Lippincott Williams \& Wilkins, Baltimore, pp 271-285

Kris-Etherton PM, Harris WS, Appel LJ (2002) AHA Nutrition Committee. Fish consumption, fish oil, omega-3 fatty acids, and cardiovascular disease. Circulation 106:2747-2757

Little DC, Kundu N, Mukherjee M, Barman BK (2002) Marketing of fish in peri-urban Kolkata. Institute of Aquaculture, University of Stirling http://www.dfid.stir.ac.uk/dfid/nrsp/kolkata.htm

NYSDOH (New York State Department of Health) (2007) Hopewell precision area contamination: appendix C-NYS DOH. Procedure for evaluating potential health risks for contaminants of concern. http://www.health.ny.gov/environmental/investigations/hopewell/appendc.htm

Powers KM, Smith-Weller T, Franklin GM, Longstreth WT, Swanson PD, Checkoway H (2003) Parkinson's disease risks associated with dietary iron, manganese, and other nutrient intakes. Neurology 60:1761-1766

Shukla HC, Gupta PC, Mehta HC, Hebert JR (2002) Descriptive epidemiology of body mass index of an urban adult population in western India. J Epidemiol Comm Health 56:876-880

Sivaperumal P, Sankar TV, Viswanathan NPG (2007) Heavy metal concentrations in fish, shellfish and fish products from internal markets of India vis-a-vis international standards. Food Chem 102:612-620

Song B, Lei M, Chen T, Zheng YM, Xie YF, Li XY, Gao D (2009) Assessing the health risk of heavy metals in vegetables to the general population in Beijing, China. J Environ Sci (China) 21:1702-1709

Speedy AW (2003) Global production and consumption of animal source foods. J Nutrition 133:4048-4053

USEPA (United States Environmental Protection Agency) (1989) Office of Water Regulations and Standard: Guidance manual for assessing human health risks from chemically contaminated, fish and shellfish U.S. Environmental Protection Agency, Washington, DC; EPA-503/8-89-002

USEPA (United States Environmental Protection Agency) (2011) USEPA Regional Screening Level (RSL) Summary Table: November 2011. Available at: http://www.epa.gov/regshwmd/risk/human/Index.htm, last update: 20th January, 2014

USEPA (United States Environmental Protection Agency) (2012) EPA Region III Risk-Based Concentration (RBC) Table 2008 Region III, 1650 Arch Street, Philadelphia, Pennsylvania 19103

USFDA (1993) Food and drug administration, Guidance document for nickel in shell fish. DHHS/PHS/FDA/CFSAN/office of seafood, Washington, DC

Vahter M, Berglund M, Akesson A, Liden C (2002) Metals and Women's Health. Environ Res 88:145-155

Zodape GV (2014) Metal contamination in commercially important prawns and shrimps species collected from Kolaba market of Mumbai (west coast) India. Int J Agrisci 4:160-169

\section{Submit your manuscript to a SpringerOpen ${ }^{\circ}$ journal and benefit from:}

- Convenient online submission

- Rigorous peer review

Immediate publication on acceptance

- Open access: articles freely available online

- High visibility within the field

- Retaining the copyright to your article

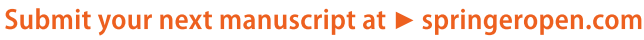

